\title{
RECOLLECTIONS OF JOHNSON COUNTY BENCH AND BAR.
}

BY THE EDITOR.

6rif ) (3) in 1849 , when the editor of this magazine first came there to reside. His introduction to the Judge, in the spring of 1851, was in this wise: Mr. George @) : Andrews loaned a mischievous mule for the writer to of ride, as out of health; for riding is the way to regain ई health, and walking to retain it. The mule saw a stud of colts running through the alley back of the house of Colonel Trowbridge, now acting Librarian or Custodian of the State Historical Society. The mule stopped instantly, and his rider went on to the ground. Judge Carlton, on his way home to a late dinner, as was his wont, ran up and inquired: "Are you hurt?" "Not much, as I had not far to fall-a short horse is soon curried." Thus, then and there, on Iowa avenue, began our acquaintance, which continued until he died - too early died.

Judge Smith, of Marion, followed him on the Bench. He was a very pleasant and prompt presiding officer, and was a law pupil of Judge Carlton.

RECOLLECTIONS OF GILMAN FOLSOM.

He was at the head of the Bar, in 1849. He was a very remarkable genius. Before he was nine years old he had read Rollin's Ancient History and other books beyond his age. He received his chief academic education at Captain Partridge's Military School in Vermont. He read Latin, French, and studied mathematics there, and became a very good belles-lettres scholar. The influence of Captain Partridge over young Folsom was good. The Captain had been a Professor at West Point Military Academy, under the United State Government, and being in some way disaffected, he left, and founded the Vermont institution, now known as Norwich University, on the Connecticut River. He was wont to teach his pupils that "MOses WAS THE GREATEST General of antiquity." 
Mr. Folsom, in 1840 , was in very successful practice at the Bar of Johnson county, and, subsequently, in the United States Courts of Iowa. Had he been industrious and sober, and devoted to his profession, he might have been most eminent in the law.

Once, before Judge Love, he called attention, in a patent right case, to the fact that the parties suing his client had shown no title to the patent. Quoting Scripture, he said: "Let him that is without fault, throw the first stone." And there the suit fell and ended. In criminal cases, he was very expert. He had the best memory of any man at the Bar. He never used paper or peneil, but trusted his memory only. In examining a witness, he would go right to the case in hand, and never attempt to puzzle or mislead a witness; and would get all he wanted from a witness in a very short time, and with very few words.

He was very shrewd and quick at repartee in court. On one occasion, W. P. C. was opposed to him in a probate suit. Folsom presented a bundle of receipts, and said the money doubtless had been paid by the administrator, his client. He handed them to W. P. C., who replied that they were good for nothing, as evidence, without affidavits attached, and added that the attorney could not be very well posted in the law of the case. Mr. Folsom replied: "I confess, your Honor, that I am not very well posted in the law of the case. I have been building a house-carrying the hod. And I submit to your Honor that I am better fitted to-day to carry the hod than to plead this case. But pray, your Honor, what has my learned friend been doingcarving geese at the Crummy House. And I submit to your Honor, whether he is not better fitted to carve a goose now than to plead this case. A universal burst of laughter from Judge Lee, the lawyers, and all parties present, suspended proceedings some minutes.

On another occasion, the same attorney said to Judge Smith: "I do not wish to be interrupted, nor to get into a general dog fight." To whom Mr. Folsom retorted: "I submit 
to your Honor that my learned friend is not a dog. If he is, he is not a full-grown one!"

His last remarkable plea was in a criminal case, where the jury brought in his client as guilty, but recommended him to the mercy of the court. "Guilty, but recommend to mercy," he said, with sarcastic tones. Out of court he called the jury twelve asses. And at the Bar supper, when called upon for a speech, he said: "Gentlemen, I have been studying Natural History of late-a very good study, which I reeommend to young lawyers. My great aim has been to ascertain

Whether twelve asses from Abyssinia can bray

As loud as one war-horse from the desert can bray.

Those present needed no interpreter to understand, that Judge Conklin was the war-horse and the twelve jurymen the asses.

A day or two after, he met one of the jurymen, who asked him, "Mr. Folsom, are you a horse-doctor ?" Not thinking of his design, he replied to him, "No! I guess you have mistaken me for a horse-doctor, Mr. Agnew, at Rider's stable." Soon after, he met another of the jurymen, who asked, "Mr. Folsom, are you a horse-doctor ?" "Oh yes!" he replied, "but a better doctor of asses than of horses. I cured a dozen the other day at one dose." This was after he made his famous plea for a new trial, and won it. In this plea he transcended himself. He gave the evidence, and showed its insufficiency to convict his client, in common style of address at the Bar. He then went into the medical jurisprudence of the case, and finally introduced the literature of the case, quoting Shakespeare, - where, in their eagerness to kill some one, they hung the wrong man. "So," said he, "the jury wishing to punish somebody for abusing the war-widows, have convicted my client, and then recommend him to mercy!"

In another case, where real estate was involved, he impatiently sauntered up to the corner of the Judge's desk, and said, in the midst of the trial, "My client has shown that he has a share in the property-by C. G. - and the other purty has shown no title whatever. I submit to your Honor that 
my client owns the property." There the case fell, and his client was acquitted by the jury without leaving their seats.

Never was there such pleading at the Johnson county Bar as Gilman Folsom's argument, above recited, for a new trial. Judge Conklin said he never heard such a masterly plea. Others remarked: "What a pity Mr. Folsom would not soberly apply to his profession." All said it was a most remarkable effort.

The writer, by his invitation, spent a winter in his family, and had an opportunity to learn his inmost character. $\mathrm{He}$ called him (the writer) his private chaplain. On several Sabbath mornings he called all his household together, and had family worship, or reading of the Scriptures and prayers. On one such occasion he accompanied the writer to the Presbyterian service, and he heard (there being an exchange of preachers) Dr. Fuller, of the Methodist Episcopal Church instead of the Preshyturian pastor. Doctor Fuller preached a very good sermon, but used one expression a little out of pulpit or correct style, "The gymnasties of the mind." Mr. Folsom said, after service, "I would not use that expressionit is not in good taste." Mr. Folsom had a very pure classic taste and style at command. Very few knew what a delicate literary taste he had. He often said: "Mr. H., I am a Puritan-I'm a Puritan." He would have no other books on his parlor center-table than the great family Bible and Watt's and Select Hymns, the Psalmody that his old minister in New Hampshire used, a copy of which he obtained for his minister, Mr. Davis, a Congregational preacher visiting him.

He once, in the presence of his family and the writer, east into the fire a general school history, because he said it was not true in particulars of English history, in regard to which his memory differed from Mr. Goodrich, the compiler. But it is proper to add that there is very great discrepancy in English sources of history, so that no two agree.

Mr. Folsom's habits, which harmed his usefulness and shortened his days, are too well known in Iowa to need comment. He never kept liquor in his house, unless confined by 
sickness, when he usually sent for it, as he wanted it or craved it. His last illness was the natural result of his course of life, over which, as a friend, the writer must draw a veil. He used to say, in comparative health, " $T$ ' $m$ a standing temperance lecture to all the young men of the city." When asked, two or three weeks before his death, to visit a farmer friend, he said: "I shall never visit your farm. My brain doesn't work"- putting his hand to his head. And, when confined to his home, he said, "I'm DOOMED To DIE!"

Thus passed away one of the greatest of men by nature, who never forgot anything! "I wish I could forget somethings," he would say. He had three dialects-the low, the common and the classic English. He excelled in each.

\section{THOUGHT IN EDUCATION.}

BY JAMES F. WILSON.

[An address, delivered at the dedieation of the Bloomer Public School building, at Couneil Bluffs, Friday, Angust 26th, 1881.]

Mr. President and Citizens of Council Bluffs:

MOTIVE is defined to be "that which determines the choice or moves the will; that which incites the action." It is well that many kinds of motives operate on men and communities to do proper \&) things. If we had always to wait for the best motives

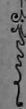
to induce individual or collective action, we would be subjected to much weary delay. The highest results are most surely and speedily attained when the purest motives induce the action which produces them. But this statement must be understood to mean that the character of the motives described must incite all of the actors necessary to the attainment of a proper end which depends upon collective movements; for it often happens that desirable results are more easily reached by the co-operative efforts of members of a community who are not all actuated by the purest motives. But these exceptions do not affect the truth of the rule stated. A community may reach a right end 
Copyright of Annals of Iowa is the property of State of Iowa, by \& through the State Historical Society of Iowa and its content may not be copied or emailed to multiple sites or posted to a listserv without the copyright holder's express written permission. However, users may print, download, or email articles for individual use. 